University of Nebraska - Lincoln

DigitalCommons@University of Nebraska - Lincoln

\title{
An annotated checklist of the horse flies (Diptera: Tabanidae) of Lebanon with remarks on ecology and zoogeography: Pangoniinae and Chrysopsinae
}

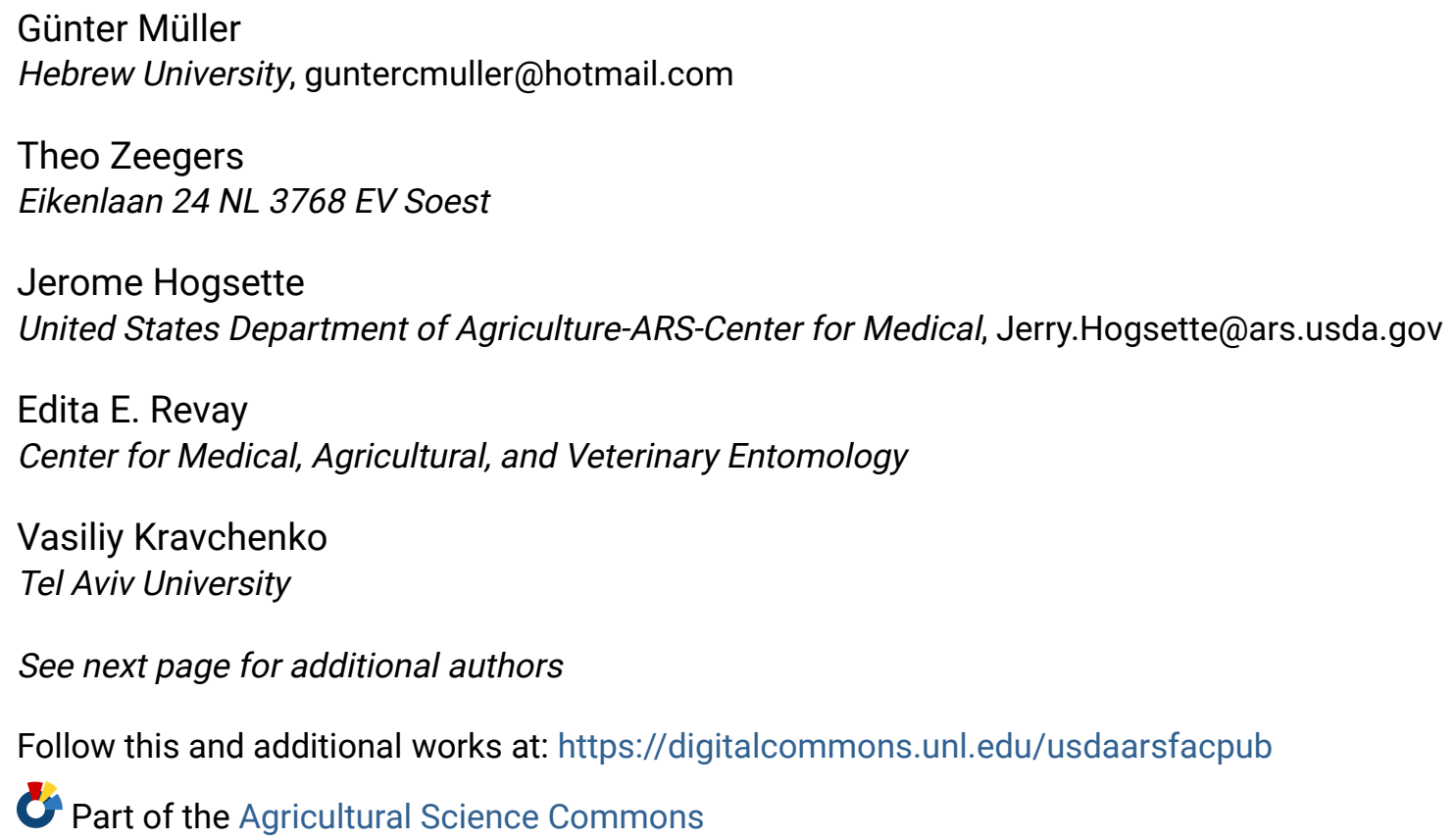

Müller, Günter; Zeegers, Theo; Hogsette, Jerome; Revay, Edita E.; Kravchenko, Vasiliy; Leshvanov, Andrey; and Schlein, Yosef, "An annotated checklist of the horse flies (Diptera: Tabanidae) of Lebanon with remarks on ecology and zoogeography: Pangoniinae and Chrysopsinae" (2012). Publications from USDAARS / UNL Faculty. 1024.

https://digitalcommons.unl.edu/usdaarsfacpub/1024

This Article is brought to you for free and open access by the U.S. Department of Agriculture: Agricultural Research Service, Lincoln, Nebraska at DigitalCommons@University of Nebraska - Lincoln. It has been accepted for inclusion in Publications from USDA-ARS / UNL Faculty by an authorized administrator of DigitalCommons@University of Nebraska - Lincoln. 


\section{Authors}

Günter Müller, Theo Zeegers, Jerome Hogsette, Edita E. Revay, Vasiliy Kravchenko, Andrey Leshvanov, and Yosef Schlein 


\title{
An annotated checklist of the horse flies (Diptera: Tabanidae) of Lebanon with remarks on ecology and zoogeography: Pangoniinae and Chrysopsinae
}

\author{
Günter C. Müller ${ }^{1 凶}$, Theo Zeegers², Jerome A. Hogsette ${ }^{3}$, Edita E. Revay ${ }^{4}$, Vasiliy D. Kravchenko ${ }^{5}$, \\ Andrey Leshvanov ${ }^{6}$, and Yosef Schlein ${ }^{1}$ \\ ${ }^{1}$ Department of Microbiology and Molecular Genetics, IMRIC, Kuvin Centre for the Study of Infectious and Tropical Diseases, \\ Faculty of Medicine, Hebrew University, Jerusalem, Israel, 91120, GunterCMuller@hotmail.com \\ ${ }^{2}$ Eikenlaan 24 NL 3768 EV Soest, The Netherlands \\ ${ }^{3}$ United States Department of Agriculture, Center for Medical, Agricultural, and Veterinary Entomology, Gainesville, FL, \\ 32608, U.S.A. \\ ${ }^{4}$ Department of Anatomy and Cell Biology, Bruce Rappaport Faculty of Medicine, Technion, Haifa, Israel \\ ${ }^{5}$ Department of Zoology, Tel Aviv University, Tel Aviv, Israel \\ ${ }^{6}$ Department of Zoology, Ulyanovsk State Pedagogical University, 432600, Russia
}

Received 11 October 2011; Accepted 10 November 2011

\begin{abstract}
Knowledge of the horse fly fauna (Diptera: Tabanidae) of Lebanon is fragmentary, while the local fauna of most neighboring countries has been fairly well researched. Within the framework of the 20 -year project "The ecology and zoogeography of the Lepidoptera of the Near East," we regularly collected biting flies in the whole region, including Lebanon. During this time we recorded 14 horse fly species for two subfamilies in Lebanon: four Pangoniinae and ten Chrysopsinae. Only a single species, Chrysops flavipes Meigen, 1804, was known previously in Lebanon, but the following four Pangoniinae: Pangonius haustellatus (Fabricius, 1781), Pangonius obscuratus Loew, 1859, Pangonius argentatus (Szilady, 1923), and Pangonius fulvipes (Loew, 1859) and nine Chrysopsinae: Silvius appendiculatus Macquart, 1846, Silvius ochraceus Loew, 1858, Nemorius irritans (Ricardo, 1901), Nemorius vitripennis (Meigen, 1820), Chrysops buxtoni Austen, 1922, Chrysops compactus Austen, 1924, Chrysops caecutiens (Linnaeus, 1758), Chrysops italicus Meigen, 1804, and Chrysops hamatus Loew, 1858 are new records for the Lebanese fauna. The Tabanidae fauna of Lebanon is completely Palearctic and most species are of a Mediterranean distribution type. Lebanon or nearby northern Israel appears to be in the Levant, the southern geographical distribution border for the Pangoniinae and Chrysopsinae. Journal of Vector Ecology 37 (1): 216-220. 2012.
\end{abstract}

Keyword Index: Tabanidae, Pangoniinae, Chrysopsinae Palaearctic, Levante, Lebanon.

\section{INTRODUCTION}

Lebanon is situated along the northeastern border of the Mediterranean Sea as a part of the Middle East and Southwest Asia. The African-Syrian Rift Valley, which defines the four prominent geographical regions: the Coastal Plain, the Lebanon Mountain Range, the Bekaa Valley, and the Anti-Lebanon Mountain Range, divides the country from south to north (Beaumont et al. 1976).

The Coastal plain is a narrow strip of fertile land between the Mediterranean Sea and the Lebanon Mountain Range. The Lebanon Mountains spread from Jebel Ansarieh in Syria to the Western and Upper Galilee, Israel, in the south. Some of the peaks exceed 3,000 $\mathrm{m}$, and the average height of the main ridge is greater than $1,500 \mathrm{~m}$ throughout. Most rivers of this range drain into the Mediterranean, often creating deep ravines. The eastern slopes of the Lebanon Mountains are part of the Rift Valley, which in Lebanon is called the Bekaa Valley. This valley has an average width of only $12 \mathrm{~km}$, and the water shed near Baalbek directs the Orontes River towards the northwest into Syria and Turkey and the Litani River to the southwest. The Bekaa Valley is dominated by agriculture and most of the former wetlands have been drained (Beaumont et al. 1976).
The Anti-Lebanon Mountains border the Bekaa Valley in the east forming the border between Lebanon and Syria. This range is lower and much more arid than its western counterpart. Towards the south, Mt Hermon, with its peak exceeding 2,800 $\mathrm{m}$, connects to the volcanic plateau of the Golan Heights (Orni and Efrat 1980).

Lebanon is part of the Mediterranean climatic zone, with its rain falling during the winter and pronounced drought during the summer. High rainfall zones coincide with the higher mountain ranges and a marked rain shadow is common in the lea of the hills occasionally resulting in an arid, even desert-like environment in the east (Biel 1944).

Lebanon is known for its diverse flora (Danin 1988) and fauna (Kosswig 1955), but the knowledge about horse flies is only fragmentary (Leclercq 1960, 1966). In contrast, the fauna of Turkey (Kilic 2006), Saudi Arabia (Leclercq 2000) Jordan (Al-Talafha et al. 2004, 2005, Müller et al. 2011b), Israel (Theodor 1965), and Egypt (Efflatoun 1930, Abu ElHassan et al. 2010) is relatively well known.

\section{MATERIALS AND METHODS}

Within the framework of the long-term project "The ecology and zoogeography of the Lepidoptera of the 
Near East" (Müller et al. 2005), horse flies were collected sporadically over the last 20 years over the entire southeast Mediterranean area, including Lebanon. But during the last five years, the efforts regarding this group were significantly intensified (Müller et al. 2011a, b, c, 2012). Without attempting quantitative analysis, horse flies were sampled from all mayor habitat types with sweep nets and Malaise and water traps (Chvala et al. 1972). The collected material was identified based on the publications of Austen (1920, 1922, 1924), Leclercq (1960), Theodor (1965), Chvala et al. (1972), and Al-Talafha et al. (2004), and using the Tabanidae collections of the Zoologische Staatssammlung München (ZSM) Germany, and Tel Aviv University (TAU) Israel. The definition of the chorotype is based on actual distribution patterns and corresponds to the definitions used in the book series, "The Lepidoptera of Israel" (Kravchenko et al. 2007a, b). Voucher specimens of the discussed species are deposited in the ZSM, TAU, and the private collection of the first author. In the following checklist, the distribution of each species is summarized according to Chvala et al. (1972) and Chvala (1988).

\section{RESULTS}

During the present survey, fourteen species, four Pangoniinae and ten Chrysopsinae, were collected in Lebanon. Only a single species, Chrysops flavipes Meigen, 1804, was known previously from Lebanon but the following four Pangoniinae: Pangonius haustellatus (Fabricius, 1781), Pangonius obscuratus Loew, 1859, Pangonius argentatus (Szilady, 1923), and Pangonius fulvipes (Loew, 1859) and nine Chrysopsinae: Silvius appendiculatus Macquart, 1846, Silvius ochraceus Loew, 1858, Nemorius irritans (Ricardo, 1901), Nemorius vitripennis (Meigen, 1820), Chrysops buxtoni Austen, 1922, Chrysops compactus Austen, 1924, Chrysops caecutiens (Linnaeus, 1758), Chrysops italicus Meigen, 1804, and Chrysops hamatus Loew, 1858 are new records for the Lebanese fauna.

\section{Annotated checklist of the Pangoniinae and Chrysopsinae of Lebanon}

\author{
Pangoniinae \\ Pangonius, Latreille, 1802
}

Pangonius haustellatus (Fabricius, 1781)

Type locality: Spain; chorotype: Mediterranean, in the west from Spain through Mediterranean Europe to Turkey, in northern Africa known from Morocco, Algeria, and Tunisia; this is the first record from the Levant. One male and one female were collected within the same day $10 \mathrm{~km}$ north of Qoubaiyat in early June, 1992 while feeding on Lythrum salicaria L. (Lythraceae). This large and characteristic species has never been observed since.

Pangonius obscuratus Loew, 1859

Type locality: Rhodes Island, Greece and the nearby Turkish shore; chorotype: Mediterranean, in the west from Spain and Portugal, in the east from Bulgaria, Greece, and
Turkey; this is the first record from the Levant. One female each was collected at the coastal plain of northern Lebanon near El Mina in mid-April, 1996 and near Al'Abdah in early September, 1998. The two specimens were collected from yellow flowering Compositae.

\section{Pangonius argentatus (Szilady, 1923)}

Type locality: Syria Akbes, Turkey Amasia, and Taurus; chorotype: East-Mediterranean, so far known only from Turkey and Syria; this is the first record for Lebanon. More common and widely spread than $P$. obscuratus but so far only recorded from the Mediterranean coast and the foot hills of the nearby Lebanon Mountain Range. In Lebanon, this species was observed from early May to mid-June. All records are from flowers and sweeping vegetation.

Pangonius fulvipes (Loew, 1859)

Type locality: southeastern part of Turkey; chorotype: East-Mediterranean, from Italy through the Balkans and Greece to Turkey; from the Levant so far only known from Syria. Along the Mediterranean Coast, wide spread but less common towards the south. In the Bekaa Valley probably rare and local, and so far seen just once along the River Orontes. In Lebanon, specimens were observed from midMay to mid-June feeding on numerous types of flowers along watercourses but especially on L. salicaria and Vitex agnuscastus L. (Lamiaceae).

\section{Chrysopsinae \\ Silvius Meigen, 1820}

\section{Silvius appendiculatus Macquart, 1846}

Type locality: Algeria; chorotype: Mediterranean, a rare species so far known only from Spain (Portillo 2002), Algeria, Tunisia (records in ZSM), and Syria. In Lebanon, only two specimens were taken in a single day, in mid-May, 2005, $10 \mathrm{~km}$ northeast of Tyre; one specimen from grazing cattle and the other while trying to feed on the arm of the collector. The habitat was dry, open bush land close to the Litani River.

\section{Silvius ochraceus Loew}

Type locality: Mermeriza, Turkey; chorotype: East Mediterranean-Iranian, known from Turkey and Iran; this is the first record from the Levant. It is rare in Lebanon, with only a single specimen collected together with numerous other tabanids in mid-May 2005, $10 \mathrm{~km}$ northeast of Tyre, from cattle grazing along the banks of the Litani River.

Nemorius Rondani, 1856

Nemorius irritans (Ricardo, 1901)

Type locality: in present day Turkmenistan; chorotype: East Mediterranean-Turanian, from eastern Turkey through Iran and Turkmenistan to Afghanistan; in the Levant so far known only from Iraq (Leclercq 1963), Jordan (Müller et al. 2011b), and western Saudi Arabia (Müller et al. 2011a). In Lebanon, this species was observed only once while it was 
attacking a group of donkeys in large numbers with several Tabanus sp. N. irritans clustered on the legs of the donkeys, while the larger Tabanus were feeding mainly on the back and shoulders of the same animals. Only N. irritans was easily diverted and persistently attacked the collector. We made this observation in early September, 2009 in the southern region of the Bekaa Valley near the Qaraoun water reservoir; at this occasion we collected a short series of the same species.

\section{Nemorius vitripennis (Meigen, 1820)}

Type locality: Belgium; chorotype: MediterraneanTuranian, from Spain through the north Mediterranean countries, penetrating Central Europe, to Ukraine eastwards from Turkey and Iran to Central Asia; in Lebanon this species was observed only once in late May, 2005 on a group of cows grazing on the slopes of the northern part of the Anti-Lebanon Mountains $800 \mathrm{~m}$ a.s.l. near Al Labwah. This species, like its congener, was easily diverted from the animals and persistently attacked the collector.

\section{Chrysops Meigen, 1803}

\section{Chrysops flavipes Meigen, 1804}

Type locality: not given, but probably Europe; chorotype: West Palearctic, from Northern Africa (Morocco and Algeria) and Southern Europe through Turkey and Iran to Central Asia, penetrating the Oriental region in northern India; in the Levant known from Syria, Lebanon, Israel, and Jordan. This species was recorded for the first time in Lebanon near Beirut 1856 by Loew as Chrysops punctifer. C. flavipes is the most common Chrysops in Lebanon and the entire Levant. Apart from the desert, it can be found in all types of habitats. In lower elevations, it occurs from late March to early November but is most common from May to September. In the mountains up to $2,300 \mathrm{~m}$, we observed this species in July and August. Females were collected on horses, donkeys, cows, camel, goats, and even dogs. In some areas in the Levant this species can be a severe nuisance for man. Both sexes were frequently collected while sweeping vegetation, from direct observations on flowers, with Malaise traps, and occasionally in yellow and water traps.

\section{Chrysops buxtoni Austen, 1922}

Type locality: Zikron Jakov (Israel); chorotype: endemic of the Levant. Until now, this species was known only from Israel (Theodor 1965), Iraq (Kroeber 1938), Turkey (Kilic 2006), and as the subspecies C. buxtoni armeniensis Olsufjev, 1977 from Armenia (Olsufjev 1977). According to Theodor (1965), the record of Kroeber (1938) from Mesopotamia, later quoted by Leclercq (1960), is an obvious mistake. In Israel, it is restricted to the Coastal Plain and the foothills of the Central Mountain Ridge with few records from Latrun (30 km west of Jerusalem), and from Hadera northwards to Haifa (Theodor 1965, unpublished data of the authors). In Lebanon this species is local and uncommon, and so far all records are from April to June and from the coastal plain near Sidon. Most specimens were collected from flowering
Umbelliferae and Compositae, and a single specimen was taken while attempting to feed on the leg of the collector. We did not observe this species feeding on animal hosts.

\section{Chrysops compactus Austen, 1924}

Type locality: Hula Valley, Israel; chorotype: endemic of the Levant; in the Levant so far known only from Israel (Theodor 1965), Turkey (Kilic 2006), and Iraq (Kroeber 1938). According to Theodor (1965), the record of Kroeber (1938) from Mesopotamia, later quoted by Leclercq (1960), is an obvious mistake. The records published by Theodor (1965) were restricted to the Hula Valley and only recently was this very rare species also found in the hills of the Galilee, the Golan Heights, and on Mt. Hermon up to $1,400 \mathrm{~m}$. In Lebanon, two females were collected midMay, 2005 by sweep net from herbaceous vegetation at the edge of a small oak forest near Chbeil, $10 \mathrm{~km}$ northeast of Marjaayoun. This location is situated on the northern slopes of the natural extension of the Hula valley, less than $30 \mathrm{~km}$ from the Israeli border.

\section{Chrysops caecutiens (Linnaeus, 1758)}

Type locality: Europe; chorotype: Eurasiatic, from Europe to Turkey and Iran, through Russia to Mongolia and China; in the Levant, presently known only from Jordan and Israel (Müller et al. 2011b). In Lebanon, this rare species is restricted to the coastal plain and the Bekaa Valley, and all records are from early April to late May. Most specimens were swept from flowers, a few entered Malaise traps and a single specimen was collected in late afternoon from the legs of a donkey. One single male was collected overnight with a CDC-UV trap.

\section{Chrysops italicus Meigen, 1804}

Type locality: Italy; chorotype: Mediterranean-Iranian, from Northern Africa (Morocco, Algeria and Tunisia) through southern and central Europe to Turkey and Iran, also on the larger Mediterranean islands; apart from Cyprus, the first record for the Levant. In Lebanon an uncommon species, probably restricted to brackish marshland along the coastal plain. From north to south, increasingly rare; found from late March to mid-June. Most specimens were collected from hosts including cow, horse, and donkey; this species also readily attacks man.

\section{Chrysops hamatus Loew, 1858}

Type locality: Makri, Turkey; chorotype: East Mediterranean, from the Balkans to Turkey; first record for the Levant. In Lebanon, a single specimen was collected together with several $C$. flavipes on the back of a horse in late April, 1999, on the coastal plain north of Tripoli.

\section{DISCUSSION}

Until recently, little was known about the Tabanidae fauna of Lebanon, with no Pangoniinae, only one Chrysopsinae, and four Tabaninae recorded from the entire country. In the Palearctic region, the Subfamily 
Pangoniinae is represented with three genera Stonemyia (five species), Ectinocerella (one species), and Pangonius (32 species), (Chvala 1988). Two of the five Palearctic Stonemyia are found in Turkey/ Iran while the rest are of Far Eastern origin, and the only Ectinocerella is endemic to the Maghreb. Until now, no species of the two genera were recorded in the Levant.

The genus Pangonius (s. str.) is restricted to the Mediterranean basin but only a single species, $P$. haustellatus, is widely distributed from Northern Africa through Mediterranean Europe to Turkey. The rest of the genus clearly clusters either in the western or eastern Mediterranean. Most of the species are found in the Maghreb and Spain (20), one is endemic to Sardinia, while eight species are restricted to the eastern Mediterranean region (Chvala 1988). Two of these east Mediterranean elements, Pangonius argentatus (Szilady, 1923) and $P$. fulvipes, were previously recorded from Syria. P. haustellatus and $P$. fulvipes reach their southern distribution border in Lebanon while $P$. obscuratus and $P$. argentatus extend to northern Israel (unpublished data of the authors). In Lebanon and Israel, all Pangonius were observed on or collected directly from flowers or by sweeping flowering vegetation. In the Levant, this genus appears to be absent in areas with less than $600 \mathrm{~mm}$ of annual precipitation. The reason might be the dependence on nectar and fruit as only source of nutrition for both male and females.

The status of Pangonius fasciatus (Latreille, 1811), supposedly an endemic of Egypt, is not clear. The name of this species only appears in the Catalogue of Palaearctic Diptera (Chvala 1988) and the original publication by Latreille (1811). It is absent in an earlier version of the Catalogue of Palaearctic Diptera "Die Fliegen der Palaarktischen Region" (Kröber 1938), in all relevant publications dealing with the Tabanidae of Egypt, including the papers of Kröber (1925a,b, 1929), Efflatoun (1930), literature dealing with the AfroTropical fauna (Oldroyd 1957, Chainey and Oldroyd 1980), or the Catalog of the Tabanidae of the World (Moucha 1976). The type is supposedly in Paris and should be reexamined.

The Subfamily Chrysopsinae is represented with seven genera in the Palearctic. Three of these, Gressittia Phillip \& Mackerras, 1960 (two species), Nagatomyia Murdoch \& Takahasi, 1961 (one species), and Thaumastomyia Phillip \& Mackerras, 1960 (one species), are found in the Far East, while Surcoufia Kroeber, 1922 (one species) is endemic to the Maghreb (Chvala 1988).

The genus Chrysops (55 species) is widely distributed in the Palearctic, while the five Nemorius species are restricted to the Mediterranean-Central Asian area. Also the southern distribution border of the Palearctic members of the genus Chrysops is in the Levant, with a sharp decrease in species diversity towards the south. There are eleven taxa in Turkey (Kilic 2006), six each in Syria (unpublished data of the authors) and Lebanon (present paper), four in northern Israel, and two each in central Israel and Jordan (Theodor 1965, Müller et al. 2011b).

The genus Nemorius was only recently recorded in the southern Levant (Müller et al. 2011a,b) and N. vitripennis is the second record for this region.

The genus Silvius (13 species) is centered in the Mediterranean basin (nine species) and in the Levant, Lebanon is the southern distribution border. Though this genus readily attacks livestock and man, it is of little, if any, medical and economical importance, and most species are simply rare and local. Though S. appendiculatus was already collected in Syria, its record from Lebanon, as one of the rarest Mediterranean species, is still remarkable. In fact, most horse fly species in Lebanon are rare and often very local. Even on a good day, we hardly caught more than a dozen specimens. The limiting factor seems to be the lack of suitable breeding habitats while suitable hosts are almost ubiquitous.

Many animal and plant species found in the Levant reach their most marginal point of geographic distribution (Lattin 1967); this is especially true for Palearctic species and even more so if they depend on wetlands of any kind (Zohary 1973, Dolev and Perevolotsky 2004). Plants and animals gradually become infrequent at the periphery of their geographic distribution before they finally vanish (Hengefeld and Haeck 1982, Brown 1984), though other mechanisms have been described (Zeegers 1991). The Pangoniinae and Chrysopsinae seem to fit in the common pattern.

\section{Acknowledgments}

The authors credit the late Mr. W. Schacht, Zoologische Staatssammlung München, Germany, for encouraging us to conduct this study and for his help in identifying part of the material.

\section{REFERENCES CITED}

Abu El-Hassan, G.M.M., H.B.M. Badrawy, S.K. Mohammad, and H.H. Fadl. 2010. Cladistic analysis of Egyptian horse flies (Diptera: Tabanidae) based on morphological data. Acad. J. Biolog. Sci. 3: 51- 62.

Al-Talafha, H., Z.S. Amr, M.A. Baker, and A.K. Bader. 2004. Horseflies of Jordan. J. Med. Vet. Entomol. 18: 208-211.

Al-Talafha, H., Z.S. Amr, M.A. Baker, and A.K. Bader 2005. Systematics and distribution of horse flies (Diptera: Tabanidae) of Jordan. J. Vector Ecol. 30: 49-61.

Austen, E.E. 1920. A contribution to the knowledge of the Tabanidae of Palestine. Bull. Entomol. Res. 10: 277-321.

Austen, E.E. 1922. Further notes on the Tabanidae of Palestine, with description of new species. Bull. Entomol. Res. 13: 151-161.

Austen, E.E. 1924. Additional records of Palestine Tabanidae, with descriptions of new species. Bull. Entomol. Res. 14: 421-432.

Beaumont, P., G.H. Blake, and J.M. Wagstaff. 1976. The Middle East, a Geographical Study. London, UK: John Wiley and Sons. $572 \mathrm{pp}$.

Biel, E.R. 1944. Climatology of the Mediterranean Area. University of Chicago Press. Chicago, USA. 180 pp.

Brown, J.H. 1984. On the relationship between abundance 
and distribution of species. Am. Nat. 124: 255-279.

Chainey, J.E. and H. Oldroyd, 1980. Family Tabanidae. In: R.W. Crosskey (ed.) Catalogue of the Diptera of the Afrotropical Region. pp. 275-308. British Museum (Natural History), London. 1,437 pp.

Chvala, M. 1988. Tabanidae. In: A. Soos, and L. Papp (eds.) Catalogue of Palaearctic Diptera, Vol. 5, AthericidaeAsilidae. Akademiai Kiado. Budapest. pp. 87-171.

Chvala, M., L. Lyneborg, and J. Moucha. 1972. The Horse Flies of Europe. Entomological Society of Copenhagen, Copenhagen, Denmark. 498 pp.

Danin, A. 1988. Flora and vegetation of Israel and adjacent areas. In: Y. Yom-Tov and E. Tchernov (eds.) The Zoogeography of Israel. Dordrecht, Netherlands: Junk Publishers. pp. 251-276

Dolev, A. and A. Perevolotsky. 2004. The Red Book. Vertebrates in Israel. Israel Nature and Parks Authority and the Society for the Protection of Nature in Israel. Jerusalem. 318 pp.

Efflatoun, H.C. 1930. A Monograph of Egyptian Diptera, Part III Family Tabanidae. Mémoires de la Société Royale Entomologique de Egypt. 114 pp.

Hengefeld, R. and J. Haeck. 1982. The distribution of abundance. J. Biogeogr. 9: 303-316.

Kilic, A.Y. 2006. New additions and errata to the checklist of Tabanidae (Insecta: Diptera) fauna of Turkey. Turk. J. Zool. 30: 335-342.

Kosswig, C. 1955. Zoogeography of the Near East. Syst. Zool. 4: 49-73.

Kravchenko, V.D., M. Fibiger, A. Hausmann and G.C. Müller. 2007a. Volume 1 Erebidae. In: G.C. Müller, V.D. Kravchenko, A. Hausmann, W. Speidel, J. Mooser, and T.J. Witt (eds.). The Lepidoptera of Israel. Pensoft Publishers, Sofia-Moscow. 168 pp.

Kravchenko, V.D., M. Fibiger, A. Hausmann, and G.C. Müller. 2007b. Volume 2, Noctuidae. In: G.C. Müller, V.D. Kravchenko, A. Hausmann, W. Speidel, J. Mooser, and T.J. Witt (eds.). The Lepidoptera of Israel. Pensoft Publishers, Sofia-Moscow. 320 pp.

Kröber, O. 1925a. Egyptian Tabanidae. Bull. Soc. R. Entomologique d'Egypte. 9: 77-137.

Kröber, O. 1925b. Neue Dipteren aus Aegypten, Bull. Soc. R. Entomologique d'Egypte. 9: 232 - 243.

Kröber, O. 1929. Neue Dipteren aus Aegypten aus den Familien Tabanidae, Therevidae, Omphralidae und Conopidae. Bull. Soc. Entomologique d’Egypte. 13: 7384.

Kröber, O. 1938. Tabanidae. In E. Lindner (ed.) Die Fliegen der Palaarktischen Region, Bd. IV, 19: 1-146. E. Schweizerbart'sche Verlag, Stuttgart.

Latreille, P.A. 1811. [Articles] In: M. Olivier, (ed.) Encyclopédie Méthodique: Histoire Naturelle. Insectes. Vol. 8. Agasse, Paris. 722 pp.

Lattin, G.D. 1967. Grundrisse der Zoogeography. Jena: VEB Gustav Fischer Verlag. 485 pp.

Leclercq, M. 1960. Révision Systématique et Biogéographique, des Tabanidae (Diptera) Paléarctiques, Vol. I.
Pangoninae et Chrysopinae. Inst. R. Sci. Nat. Belg., Bruxelles. 77 pp.

Leclercq, M. 1963. Tabanidae (Diptera) of Iraq. Bull. Iraq Nat. Hist. Inst. 11: 1-12.

Leclercq, M. 1966. Révision Systématique et Biogéographique, des Tabanidae (Diptera) Paléarctiques, Vol. II. Tabaninae. Inst. R. Sci. Nat. Belg., Bruxelles. 237 pp.

Leclercq, M. 2000. A Faunistic account of Tabanidae (Diptera) of Saudi Arabia and Oman. Faun. Arabia. 18: 285-292.

Moucha, J. 1976. Horse-flies (Diptera: Tabanidae) of the world, synoptic catalogue. Acta Entomol. Musei Nat. Pragae, (Supplement 7). 319 pp.

Müller, G.C., V.D. Kravchenko, and Y. Schlein. 2005. Die Erforschung der Israelischen Lepidopteren Fauna. In: Tiere und Kunst aus Israel. K Schoenitzer, (ed.). Berichte der Freunde der ZSM 2: 30-39.

Müller, G.C., J.A. Hogsette, and V.D. Kravchenko, 2011a. New records for the horse fly fauna (Diptera: Tabanidae) of Saudi Arabia with remarks on ecology and zoogeography. Acta Parasitol. Med. Entomol. Sinica. (In press).

Müller G.C., J.A., Hogsette, E.E., Revay, V.D., Kravchenko, A. Leshvanov, and Y. Schlein. 2011b. New records for the horse fly fauna (Diptera: Tabanidae) of Jordan with remarks on ecology and zoogeography. J. Vector Ecol. 36: 447-450.

Müller G.C., J.A., Hogsette, E.E., Revay, V.D. Kravchenko and Y. Schlein. 2011c. An annotated checklist of the Stomoxyini (Diptera: Muscidae) of the Levant with new records from Lebanon, Syria, Jordan and Sinai Egypt. Acta Parasitol. Med. Entomol. Sinica. (In press).

Müller, G.C. V.D. Kravchenko, A. Junnila, and Y. Schlein. 2012. Tree-hole breeding mosquitoes in Israel. J. Vector Ecol. 37: 102-109.

Oldroyd, H. 1957. The Horse-flies (Diptera: Tabanidae) of the Ethiopian Region III: Chrysopsinae, Scepsidinae, and Pangoniinae and a Revised Classification. London British Museum. 489 pp.

Olsufjev, N.G. 1977. Slepni, Tabanidae. In: Fauna SSSR, Nasekomye Dwukrylye, part VII (2). Izdatelstwo Nauka, Leningrad. $436 \mathrm{pp}$.

Orni, E. and E. Efrat. 1980. Geography of Israel. Fourth revised edition. Jerusalem: Israel University Press. 556 pp.

Portillo, M. 2002. Diptera Tabanidae. Fauna Iberica, Volume 18. Museo Nacional de Ciencias Naturales. Madrid. $309 \mathrm{pp}$.

Theodor, O. 1965. Tabanidae of Israel. Israel J. Zool. 14: 241 257.

Zeegers T. 1991. On fluctuations in the population density of the hoverfly Eristalis pratorum. Nonlinear Dynamics (Twente University): 74-95.

Zohary M. 1973. Geobotanical foundations of the Middle East. Stuttgart, Germany: Gustav Fischer Verlag. 739 pp. 